\title{
Producing landscapes of environmental justice: exploitation of woodlands and wetlands and deep historical geographies of justice on Gotland
}

\author{
Tom Mels
}

Received: 9 July 2020/Accepted: 15 June 2021

(C) The Author(s) 2021

\begin{abstract}
Context The importance of justice is increasingly recognized in environmental policy making. Research on environmental justice offers an important perspective on landscape transformations, both natural and social.

Objectives This paper asks how current work on environmental justice might contribute to the development of socio-environmental knowledge of the biophysical landscape. The paper explores the relations between environmental justice thinking and the production of a distinctively capitalist landscape.

Methods The paper builds on a review of environmental justice and landscape literature and, for the empirical part, on archival studies and secondary sources.

Results The paper shows that there remains a disjunction between landscape studies and the environmental justice literature. It provides a theoretically informed approach of bringing together environmental justice scholarship with the transformations of a contested and distinctively capitalist landscape. By studying changes in woodlands and wetlands on the island of Gotland, Sweden, it uncovers a process of the production of landscape that elicits "deep" historical
\end{abstract}

T. Mels ( $\bowtie)$

Department of Social and Economic Geography, Uppsala University Campus Gotland, Cramérgatan 3,

62167 Visby, Sweden

e-mail: tom.mels@kultgeog.uu.se geographies of environmental justice. The massive exploitation of wetlands and forests shows how an approach encompassing environmental justice in conjunction with forms of resource exploitation and conservation can help grasp changes in the landscape.

Keywords Capitalism - Draining - Environmental justice · Gotland · Landscape ecology · Logging · Wetlands

\section{Introduction}

What is to be gained from coordinating the study of the biophysical landscape with environmental justice scholarship? The question may seem to ask for the obvious, because discussions about environmental justice are often precisely about the patterns and events that produce the landscape. After all, the landscape materially crystallizes forms of justice and injustice. At each moment in its historical transformation, the landscape deposits in its material form, assets and burdens of environmental change. If environmental justice asks questions and offers normative answers about, for example, the uneven societal patterns and processes of environmental harm, then landscape studies precisely concern the different environments in which struggles over these relationships tend to take shape. Congruently, if we think of environmental justice as an ideal, then it informs or 
interrogates the practices, procedures and policies that shape already-existing landscapes (Holifield et al. 2010). While the landscape, like justice, can be seen as an expression of ideals - as forms of perception, symbolic representation and meaning-it is thus simultaneously the material, bio-geophysical result of social practices that give shape to environmental justice throughout history. On closer inspection, however, the relationship between landscape and environmental justice has also proven to be less than obvious. There remain considerable scholarly variations concerning in what manner and to what extent this material and ideological production of landscape is recognized in research. Despite the now rather widely acknowledged commonalities and connections between landscape, environmental concern and justice thinking, they have been pieced together in fragmented ways. This contribution lays out an approach to landscape that takes seriously the struggle over environmental justice as part of the socio-environmental production of landscape, which is to say, of the specific material and discursive conditions and relations that go into its making. It argues that while the production of landscapes is shaped by and shapes struggles over environmental justice, it is neither subservient to, nor exhausted by the dynamics of these struggles. What I mean to say is that in order to align a concern with environmental justice to changes in the landscape, it is necessary to examine the broader conditions under which landscapes are produced. For contemporary landscapes, the conditions of capitalist production are hence central to current developments regarding environmental justice.

The paper sets out, firstly, to explore the current status of environmental justice writing, and argues that it provides vital ingredients for the development of socio-environmental knowledge of landscape. Three key dimensions of justice are vital here, both theoretically and empirically: (socio-economic) distribution, (cultural) recognition, and (political) participation (Fraser 2003, 2009). Secondly, and by extension, it presents these dimensions as significant moments in the historical production of landscapes, provided that they always need to be contextualized as signifying practices and material relationships. In other words, environmental justice is part of a set of internal relations through which the production of landscape evolves. In capitalist society, the production of landscape is profoundly conditioned by the power of accumulative interests, which also, by extension, conditions the way distribution, recognition and participation attain shape empirically. Thirdly, this implies that circumstances of environmental justice do not appear at a set point in landscape history: they need to be seen as already-existing moments of the landscape throughout its historical transformation. In that respect it is possible, against standard histories of the environmental justice movement, to conceive of a deep historical geography of environmental justice that predates the environmental justice movement. The paper then illustrates these largely theoreticalexplanatory gains about the production of landscape and environmental justice by looking at the exploitation of wetlands and woodlands on the island of Gotland, Sweden.

\section{Environmental justice and landscape}

Research on environmental justice and the study of biophysical landscapes have different origins and have partly followed different academic trajectories. Environmental justice research emerged from a social movement that identified and documented locally occurring cases of environmental pollution and ecological harmful infrastructures in the United States. Mapping these environmentally de-graded and dangerous places in the 1970 s and 1980 s revealed the disproportionate environmental burdens on communities of color, indigenous and low-income communities (Bullard 1990). Studies also showed that low income communities and minorities are disfavored with regards to access to environmental and public health protection, support from public advocates, involvement in planning and policy making processes (Pulido 1996). From these uneven patterns of distribution, demands were formulated for a more just distribution of environmental assets, such as access to green space or fresh air, and burdens of air and water pollution, hazardous jobs, and exposure to a variety of health risks. Much of the existing inequality was traced to the outcome of official planning system procedures, policy making, and locational decisions taken by firms (Bryant 1995; Sandler and Pezzullo 2007).

From a mapping of uneven patterns of distribution, and indignation at the causal mechanisms that socially produced them (including forms of environmental 
racism), environmental justice thus morphed into a political and moral demand for recognition of the status and rights of those who were structurally neglected, as well as of citizens' possibilities to participate in decision making. Research has subsequently widened its grasp by including multiple categories of social difference, such as age, class, gender, and sexuality (Agyeman 2013; Buckingham and Kulcur 2010; Schlosberg 2007; Walker 2012). It thereby developed a stronger connection to political philosophies of (socio-economic) redistribution, (cultural) recognition, and (political) participation (Fraser 2003). Through property relations and questions of use, access, and design, landscapes are clearly implicated in distributional justice. Distributional patterns are therefore intimately related to recognition, which concerns how groups are being accepted or marginalized in place and society, stereotyped, or subjected to harmful patterns of interpretation (Taylor 1992). Finally, the issue of participation acknowledges the importance of different people's involvement in social life. It raises questions about whose discursive version of reality and, more specifically, whose environmental interests are being included, represented, or ignored in the remaking of landscapes and social space (Fraser 2009; Young 1990).

What Pellow and Brulle (2005) call critical environmental justice represents the most recent extension in the field, and it brings out two particular limits to environmental justice thinking that warrant attention here, not least from a landscape perspective (Pellow 2016). In the first place, Pellow suggests transhistorical human concern with the politics of environmental justice, and one that transcends local scales of inquiry. If "environmental injustice reaches back centuries," then a study of the past will arguably unveil "the long Environmental Justice movement" (Pellow 2018, p. 9). Geographically too, Pellow insists on the recognition of what takes place on different scales (the local and global are not separate realms) rather than limiting analysis to the environmental justice movement's traditional sensitivity to place-bound experiences. This perhaps straddles the boundaries of what is conventionally considered a (let alone the) movement (i.e., an identifiable group of people organized around a common agenda), but it is nevertheless crucial for coming to terms with the multiple historical and geographical relations that produce landscapes of injustice.
In the second place, Pellow proposes an extension of justice thinking beyond human society and health issues (cf. Schlosberg 2013). Building on the position that excluded, marginalized groups in society are vital to our collective futures, Pellow argues for the inclusion of non-human nature too, arriving at what he calls the "indispensability" of communities. In this rendering, environmental justice (notably recognition) thus also includes ecological justice, an ethical standpoint that appeals to the consideration of "species" (Pellow 2018, p. 15). This indispensability implies that a broader set of socioecological communities qualify for recognition, because they can be affected by environmental injustices-such as uneven distribution, dispossession, oppression, and displacement—but also because they are agents in the struggle over justice and socio-ecological change more generally (Pellow 2018, pp. 19-20; cf. Honneth 2008, p. 131). This moves critical environmental justice closer to an ethics of nature's intrinsic, non-utilitarian value and other classic arguments of preservationism. At the same time, however, it remains rooted in an awareness that the environment or ecosystems are embedded in cultural contexts and social practices of meaning.

Against the background of these developments, which included a steadily expanding empirical concern with environmental injustices of agricultural land grabbing, deforestation, mineral resource extraction and aquatic, atmospheric and terrestrial pollution around the world, the traditional focus of mainstream environmentalism is also beginning to change. The latter's preoccupation with nature conservation and its inattention to social inequalities has moved to an emerging policy agenda of "just sustainability," where environmental quality and social equity are far more pronounced while underlining the importance of place and everyday cultural landscapes (Agyeman 2013; Agyeman et al. 2003). In mainstream environmental policy making, recent references to justice in the EU's European Green Deal, the UN's global Sustainable Development Goals, and the work of The International Union for Conservation of Nature (IUCN) may perhaps serve as examples, although there seems to remain a conspicuous difference between green rhetoric and actual policy making. Whether this is more than paying lip service to an increasingly global environmental justice concern arguably remains to be seen. Perhaps more concretely, 
local sustainability initiatives and practices that exist outside the scope of such larger agendas may illustrate the just sustainability ideal (Krueger and Agyeman 2005).

In sum, from developments in environmental justice writing, we can discern a theorization of uneven forms of distribution, recognition, and participation. These justice concerns are extended to nonhuman nature, and there is also a consideration of the embodiment of multiple scales and histories of environmental justice in the landscape.

\section{Landscape studies and environmental justice}

Landscape studies have a far longer history as a field of study, reaching back decades in various disciplines, and most readers will be familiar with at least some of its earlier transformations. It shares with environmental justice scholarship, an interest for the natural world, but also, albeit more recently, a substantial engagement with justice (Mels 2016). This interest for questions of social justice and rights to landscape is not least sensed in the surge of work-notably in geography and landscape architecture-on landscape as a political place and polity, on the right to the landscape, and landscape democracy (Egoz et al. 2018; Olwig and Mitchell 2008). The European landscape convention, with its allusion to the importance of citizen's perception, formed a policy backdrop to some of these discussions (Jones and Stenseke 2011). For a number of scholars, the question of nature and environment features prominently, extending the long haul of cultural geography's interest in the matter of environmental change (Olwig 2019). Paralleling recent dispatches from environmental justice scholarship, cultural landscape studies have conceptualized nature, ecosystems and the environment, as powerful social constructs, as concepts with considerable ideological ramifications: they may have a status as biophysical realities, but they can only be understood and provided with meaning from within a discursive and social context (Matless 2012; Smith 2010).

The emergence over the course of at least the last three decades of a concern with nature as a social construct, with justice in cultural geography (and the development of environmental justice from distributional issues to issues of political participation and recognition), all took place in an international scholarly dialogue with developments in the broad spectrum of (critical) social theory and post-positivist philosophy. In geography and other disciplinary fields, some of these have taken a radically discursive route to the study of representations of landscape in imagery and texts (Cosgrove and Daniels 1988), while others have emphasized the importance of a wider array of bodily and physical practices (Wylie 2007), and still others - to revisit the terminology of my introduction-the ideological and material production of the landscape, especially in the context of capitalist society (Mitchell 2012).

This conception of production needs further qualification, which I will provide in the next section. Before anything, though, it is important to point out that the developments cited above have not given way to any explicit dialogue between the fields of environmental justice and landscape ecology (cf. Bryant and Callewaert 2008). Granted, in landscape ecology too, it is no secret that definitions and perceptions of the environment and sustainability, and scientific concepts such as biodiversity or ecosystem, are diverse in research and policy making (Wu and Hobbs 2002; Naveh 2007; Metzger 2008; Musacchio 2013). At the same time, the field's cross-disciplinary dialogue generally took a different, partly more natural science and quantitatively oriented route of enquiring the reciprocity of landscape patterns and ecological processes (Farina 2006). This may help explain why issues of justice, including environmental justice, and its socio-cultural critique of distribution, participation and recognition receive limited consideration in landscape ecological writing (cf. Chen et al. 2019).

\section{The production of landscape and boundary struggles}

From this brief excursus on environmental justice and landscape research, and for all their diversity, we are now in a position to sort out two features. Environmental justice scholarship has been cognizant of landscape and the importance of place, while being less attentive to profound ways in which capitalist production remakes those landscapes. The latter needs to be part of the equation for environmental justice to gain more explanatory power. In that respect, Krueger and Agyeman's diagnosis that, for all its pertinence as a revealer of inequalities, "the environmental justice 
literature is more a political strategy than a theoretical approach" and that it has not been sufficiently capable of revealing the wider socio-economic processes shaping "local places experience", still holds true (Krueger and Agyeman 2005, p. 415). If we turn to the field of landscape research, a slightly different image emerges. There has been considerable focus on environmental change and discursive and material production of landscape, and also on social justice, but it has largely stayed clear of analyzing these moments in terms of environmental justice. This is not to say that the two fields are worlds apart. To the contrary, and I will tentatively argue for a particular realignment of the production of a landscape approach and the concern with environmental justice.

The conception of production to which I have been referring above, and which has been adopted and adapted in recent writing on nature and landscape (e.g. Mels 1999; Mitchell 2012), originates from the heterodox Marxist thinker Henri Lefebvre. Notwithstanding an important degree of persistence of the landscape and associated signifying practices, said Lefebvre, each historical mode of production (such as feudalism or capitalism) can be expected to produce its own space, conditioned by, and adapted to its special requirements (Lefebvre 1991). This process of production, which, needless to say, includes various kinds of exploitation of natural resources, has far reaching implications for justice conditions in society.

From one point of view, the landscape around stands out as an immeasurably important work, formed collectively through labor, and providing for human subsistence by the appropriation of nature over centuries. This includes poiesis, or the creative thought-action of human beings who appropriate both external and human nature and thereby form the landscape as a work rather than commodified product. It thereby evokes the creator's entitlement, the normative right to the landscape as a place of cohabitation, everyday life, participation, and use value. Questions of justice and the right to appropriate landscape as an everyday place and repository of natural resources thus follow from the history of landscape's production. Such historical claims to rights and justice clearly remind of Pellow's more specific reference to the long history of environmental justice movement, which could be generalized as a "deep historical geography of environmental justice" (Mels 2020). Identifying how the historically specific production of landscape conditions environmental justice, this is not limited to an easily identifiable modern movement with a common activist agenda steeped in the science of ecology. It also encompasses more fragmented expressions of environmental justice concerns with landscape ecologies.

From another point of view, however, such deep historical geography tends to be characterized by highly uneven developments. Especially under the influence of the instrumental rationality that configures capitalist modernity, the landscape emerges as a more alienated product rendered in a commodified form as private property and exchange value (Lefebvre 1968). Such diverse ways of transforming the landscape, as Lefebvre shows, always goes hand in hand with a host of practices of representation and signifying the landscape. This notion of productionwith the insistence on the history and present of representational and practical intervention in the landscape and its insistence on rights-is compatible with the insight that the environment we encounter in everyday life no longer stands out as independent, but as a richly political and social product, indeed encompassing the production of nature (Smith 2010).

At first sight, this may seem little different from the broad social constructivism described earlier. However, the notion of production refers here to the necessity of a materially grounded approach that is differentiated by history and geogrl=The contemporary hegemony of capitalist production on all geographical scales-which is simultaneously involved in all sorts of discursive and material practices - creates new landscapes and ecologies, both intentionally and unintentionally. Nonhuman nature itself, as a realm of use values, becomes increasingly part of the logic of commodification and economic growth. This is not to say that nonhuman nature or landscapes are stripped of any causal power or agency vis-á-vis capitalist processes. It is to concede that they are a medium and outcome of such dynamic processes (Harvey 1996).

Capitalist production presupposes a constantly shifting frontier of commodification, which has been vividly described by critical theorist Nancy Fraser. Nonhuman nature, she notes, is one of capitalism's conditions of possibility, and arising with capitalism there are incessantly mutating attempts at demarcating the non-human from the human in what she calls "boundary struggles" (Fraser 2014, p. 68). Non- 
human nature appears here as a core background condition of capitalist production, treated and incorporated as a collection of "raw materials" that make capital accumulation possible, with every new boundary struggle installing new versions of the commodification of nature in the course of capitalist development (Fraser 2014, p. 63). Under these conditions, appeals to the natural world cannot be severed from capitalist accumulation, including its tendencies to end up in multiple crises. As the current environmental crises show, the production of nature under capitalism threatens the ecological conditions that make accumulation possible in the first place ( $\mathrm{O}^{\prime} \mathrm{Con}-$ nor 1998).

Still, Fraser claims that these ecological conditions are not entirely subsumed under the force of capitalist accumulation but also harbor reservoirs of critical thinking and normativity that confront ongoing boundary struggles (Fraser 2014, p. 69). Pellow's indispensability argument may be a case in point, and environmental justice claims more generally-including those pertaining to landscape-could potentially be seen as part of such a reservoir of critical normativity. However, Fraser's appeal is patently more specific in that she explicitly fosters scholarly exploration of environmental justice under capitalist conditions. At the same time, her thinking remains in at least one important respect disconnected from what landscape scholars have been arguing all the while.

Although Fraser's "boundary struggles" invoke a spatial practice of sorts, her work remains remarkably silent on the way such struggles are intensely differentiated by time and location. To be sure, accumulative interests materially and discursively interweave in diverse ways with landscape ecologies, and this, in its turn, deeply affects the shape that environmental justice takes. Under such circumstances, any struggle over environmental justice arguably becomes embroiled in the struggle over accumulative interests in landscape transformation. From this, environmental justice can emerge more fully as providing evidence on historically- and place-specific grounds, but also as a critical, normative perspective which takes to task the diverse landscape ecologies produced by capitalism (cf. Walker 2012). If landscapes and ecologies are always produced and involved in boundary struggles in the way alluded to here, the difficult question is which forms of production may be beneficial to humanity in terms of political participation, economic distribution, and cultural recognition, and which are not.

It is in this context of production and boundary struggle, with landscape and nature as part and parcel of and historically co-constituted with capitalist society that I will locate the matter of environmental justice in the empirical cases explored next.

\section{Wetlands and woodlands}

Resource extraction on Gotland in the nineteenth and twentieth centuries offers a useful vista on the deep historical geography of environmental justice and its imbrications in the production of landscape. This is particularly true for two major transformations, both of which represent intense forms of commodification and capitalist exploitation of natural resources on the island: deforestation and the draining of mire wetlands. There are at least three reasons to address this particular case here.

Firstly, they represent some of the most large-scale social and ecological changes on the island since the nineteenth century, with major consequences for the production of landscape to the present. The mires originally covered about 28,000 ha or one-tenth of the island's area, and almost all were drained by the late nineteenth century. By the 1860 s official reports unanimously expressed worries about rapidly dwindling forest resources (Melin 1945, p. 345). While this encompasses a host of changes, I will primarily pay attention to the way landscape conversions (and their boundary struggles) roused environmental justice appeals.

Secondly, these two forms of resource exploitation were not separate developments, but, as I will argue, intimately connected in the capitalist production of landscape (Mels 2014). This is perhaps most obvious considering the links between the two companies that operated modern, capitalist draining and logging: the Graham Brothers Company and the Gotland Mire Company. However, logging and draining also concurrently altered biodiversity and hydrology. The link between draining and logging is important because it brings out capitalist modernity's broad sway, that is to say, its production of landscape not as a series of separate events and projects, but as a whole, and including developments in policy making and planning. The latter implies the significant role of the state 
in authorizing land reforms and legislation and other actions conditioning environmental justice.

Thirdly, the mobilization of timber resources and the cultivation of mires stirred debate about the right to landscape and the loss thereof, and also, subsequently, a number of conservation efforts that sought to resuscitate earlier boundary struggles and that prefigure the indispensability of species argument.

The account that follows is based on representative materials derived from extensive archival studies, including a broad variety of official reports and newspaper articles, and secondary literature on the subject. While I trust it is clear that I can only treat the case with limited detail here, my main aim is to illustrate the deep historical geography of environmental justice in terms of distribution, participation, and recognition. It is possible to identify a common pattern, shared by the exploitation of mires and woodlands on Gotland, in their evolution from the nineteenth century onward. I will tentatively describe them as three major interlocking developments, covering the period between the mid-nineteenth until the early twentieth century and beyond.

\section{Draining and logging}

The first development can be described as the production of a landscape of exchange value, against customary forms of subsistence and use. Although exchange and trade had long been a part of the local economy, much of the rural world, and the resources available in the mires (waterfowl, reeds, and fish) and woodlands (fuel, timber) were places of use value and subsistence, and partly common use outfields (Moberg 1938). From the perspective of local and national authorities in particular, the intensified exploitation of the landscape and its resources was seen as a necessary step towards modernization and commercialization of the rural economy (Ihre 1841; Lunddahl 1852; Runefelt 2008). These new methods of exploiting resources for exchange were widely contested boundary struggles but supported by the state and powerful capitalists. The latter included the Mire Company of Gotland: an urban elite who, backed up by legally endorsed expropriation of mires, undertook the first large-scale draining in the 1850s (Fegraeus 1888; Sylvan 1892). The initial major projects of draining and cultivating mires were also part of a politically supported commodification of resources. By the mid-nineteenth century, the mires were increasingly appropriated as one of the vital nodal points around which capitalist modernity on Gotland was organized. Disintegration of customary communities and the substitution of usevalue (e.g. hunting, fishing) and subsistence-oriented parts of the economy by surplus and exchange value were prime objectives (Mels 2014).

A major outlet for propaganda for and against draining were local newspapers. In a representative piece on "a short history of mire cultivation," it was professed that the public should be informed about the "true circumstances" in the mires: "Complaints by the mire owners about violations against property rights and averred losses are arguably already more than sufficiently disproved by official documents that confirm, to the contrary, how mire owners have already gained considerable profits from newly won, and hitherto barren, arable land, while receiving additional yields from tillage in the mire itself. These profits substantially exceed the bemoaned losses of the admittedly negligible fishery in the lakes" (GLaT 1859). The boundary struggle, according to this reading, was already decided in favor of capitalist agriculture.

The higher goal of reaping surplus value from the drained mires was repeatedly underlined throughout the nineteenth century. Critical voices would instead point out that, notwithstanding these claims to the extraction of surplus value from the land, mire draining was forced upon the peasantry. They questioned the viability of the draining project from an agricultural point of view (as I will show in a moment), but also feared it would entail the demolition of the peasantry's numerous watermills and the loss of existing resources that were extracted from the mires. Distributional justice was at stake because the exchange of property as the settlement of rights and duties of those who abstained from involvement in draining remained far from satisfactory. Assessments of expected yields in drained fields were at best speculative, and certainly underestimated the value of existing resources, including fish and fodder, from the mires. The point was that erstwhile abundant resources had been destroyed. Against contentions to the contrary, their experientially based opinion "concerning the real conditions" in the undrained mires was rather favorable: "To put it briefly, we just want to confirm that Martebo mire, in its natural state, before its reclamation, was a productive area: partly due to its 
rich and abundant fodder, and partly because of its occasional fisheries of eels and scaled fish, which gave a yearly yield without any major expenditure" (GT 1859b).

Such peasant claims to the right to the landscape as a customary, everyday place of use value were claims to environmental justice. Redistribution of land through legal provisions (non-draining peasants would lose their right to use the mires, and draining would limit their access to natural resources), lack of recognition (stereotyping of peasants as ignorant and backward in public debate), indicate that there were limits to democratic political participation in the draining debate (notwithstanding the peasantry's political influence, also in the Swedish Parliament) (Mels 2014).

Deforestation had been a matter of concern for a considerable time on Gotland, mainly due to overexploitation of wood for fuel in households and local industries, but also due to a quite extensive preindustrial export of lumber and boards to international markets in Germany and Denmark (Söderlund 1952). However, the development of logging on Gotland entered a whole new phase with the substitution of economic liberalism for earlier restrictions to logging in Sweden and the lowering of English import tariffs. These changes explain the arrival of the Scottish Graham family, who brought up woodlands for logging on Gotland. The draining efforts of the Mire Company and the development of logging were intimately related and occurred in the same period from the 1850s onwards. Peter Graham-merchant, shipbuilder, and lumber trader-shipped machinery, fertilizers and seeds to Gotland in early 1856 after initiating a series of land deals. The shipment included a highly modern steam powered portable sawmill. The lumber company's effort received support from one of the Mire company's main figures, Carl Fredrik Liljevalch senior (also active in forestry), for setting up their business. Both Alexander and Patrick Graham, who run the business on Gotland, would marry a Liljewalch, thereby strengthening ties between families. Grahamston, or the "colony", as their enterprise at Gullauser and Auster farms was sometimes called, eventually consisted of a school, an outlet, and tied cottages, with migrant workers recruited from the island and the province of Skåne.

During the 1860s and 1870s, the Gotland subsidiary of the Graham Brothers' company continued to expand their woodland property on the island and operated several newly imported mobile and stationary sawmills (GT 1859a; Sverne 1970, pp. 25-28). Some of these developments were in line with experiences in the north of Sweden. Here, the massive expansion of the timber industry after mid-century stirred a national debate around capitalist overexploitation of resources, combined with social and economic controversy over right to resources and ownership (Pettersson 2015, pp. 27-78). On Gotland, too, critical voices were raised against the advance of logging on an industrial scale.

\section{Failure and criticism}

The second development may be described in terms of failure, with both draining and logging facing major challenges. Draining would, as we have seen, radically alter customary conditions of ownership and land use of the local communities. While resistance against these changes had a delaying effect on the whole draining project, the immediate reasons for its failure largely emanated from deficient knowledge of environmental conditions (Sylvan 1899). Although the critics of draining described themselves as "simple peasants", and acknowledged that their opinions had been fervidly rejected by people "on the highest vantage point of civilization and intelligence", they did stake claims to recognition and a fairer distribution of natural resources (WW 1847a). Their understanding of the strategic calculation and underlying motives of the Mire Company was clear enough from the outset: "After preparatory groundwork by the press, Gotland's mire reclamation had gained prominence amongst contemporary issues, when English enthusiasts after a few hours or days on the island made the most attractive proposals, and when the state was brought to allot loans, etc., the time was right for the multifaceted capitalist to act in order to transform all this into large-scale speculation. Water mills are bought at a high price, leveling is done, the most brilliant proposals are sent to the appropriate authorities, and eventually to the government, and when their endorsement is gained, it is time to promulgate the upcoming major revenue in the newspapers, in order to lure fiery buyers and probably sell the entire value of shares with a considerable profit even before the first spade is put in the mire" (WW 1847a). 
This was not a prediction, the peasants claimed, but a realistic description of experiences and observations of the Mire Company's approach (Lindström 1879). Although the Company's high hopes of bringing the mires under the plough were scientifically backed up by agronomists, the latter "made big mistakes concerning reclamation of the mires of Gotland". Against those with admittedly "higher academic education in chemistry and agriculture," the peasants claimed their local knowledge of Martebo mire, which they triangulated with reference to modern science. They cited the German scientist Justus von Liebig's path-breaking book Organic Chemistry in its Application to Agriculture and Physiology, which quickly passed through a number of revised editions and a Swedish translation, to back up recognition of their voices (WW 1847b). Liebig was an internationally wellknown scholar and elected a member of the Royal Swedish Academy of Sciences in 1837. His work was also eagerly studied and commented upon by Karl Marx, who used it to explain the environmental havoc of capitalist agriculture (Bellamy Foster 2000). Pioneering the field of agricultural chemistry, Liebig famously responded to the problem of declining soil productivity in Europe and America of the 1820s and 1830s, insisting on the role of inorganic soil nutrients (and in particular nitrogen, phosphorus and potassium) in the growth of plants. This mineral theory fundamentally questioned - and eventually overthrewprevalent humus theories of the time, in which decayed plant matter (humus) was thought to be the chief nutrient of plants.

If Liebig was right, it would be fatally insufficient to rely on the humus-rich soils made available through draining the mires of Gotland and hence to put any trust in the authoritative vision of the drainers. Contrary to the empirically systematized techniques proposed by Swedish drainers, Liebig's proposition was to transform agriculture into a proper science, building primarily on chemistry. While the peasantry of Gotland could hardly live up to the standard of scientific method, their practical experiences did not seem to contradict Liebig's conclusions. At his laboratory in Giessen, Liebig and his assistants made countless analyses of ashes of plants, convincingly demonstrating that without the addition of fresh minerals, the soil would be exhausted. Against the prospect of profitable yields, the peasants too foresaw that even after additional burning, the soil would return to a state of wilderness. Moreover, they praised the mires for their fresh drinking water and life-giving hydrological conditions, contrary to the politically sanctioned belief that draining would cure the land from unhealthy and damaging occurrences of water (Säve 1980). Participation of famers and recognition of local knowledge in policy making thus seemed to be lacking, and it was pointed out that from any failure to do so, disastrous results were to be expected.

From experience it was well-known among the peasants that the productiveness of the mires depended on seasonal flooding, and any draining would entail the destruction of the natural inflow of nourishments, as exemplified by the largest wetland on the island, Martebo mire: "When the mire topsoil dries out, all that remains is often a several ells deep, porous mass. It takes decades, indeed centuries for this mass to molder away, consolidate, and become arable land. The experienced agriculturist knows that soil fertility depends as much on the underlying subsoil as on the topsoil. The subsoil in Martebo mire consists primarily of limestone deposits, elutriated calcium carbonate, which is the worst kind of soil. As a consequence, the transformation of Martebo mire into fertile land would not only require the procurement of proper topsoil, but also of suitable subsoil" (WW 1847a. The Swedish ell equaled about $0.59 \mathrm{~m}$ ). A logical inference followed: "Draining of Martebo mire will turn out as a completely destructive endeavor, as long as the widely acknowledged laws of nature persist, and for which solidity is guaranteed by God the Father himself" (WW 1847a). These divinely determined laws of nature, it was argued, were connected to experiences of what was right and just on earth and were not necessarily in line with existing legislation. Questions about ownership, the right to the landscape, and the peasants' sense of justice could therefore not be completely solved with reference to draining legislation, or, for that matter, any other legislation. To the contrary, history had proven that "laws have been invoked to support the most brutal violence, the most serious criminalities and most inhuman barbarity" (WW 1847a).

In subsequent decades, and while the claims to justice by the peasants-recognition of local knowledge and experiences, and their contribution to policy making-remained subject to continuing criticism and were ridiculed by the elite in Visby, the early assessment of agricultural conditions proved largely 
correct. Deficient knowledge of hydrology and terrain, steep costs of digging ditches and canals, and miscalculations concerning soil fertility turned the draining project into a major disappointment in the 1860s. As the draining effort ran up against the limits to agricultural engineering and soil fertility, logging resulted in deforestation and lack of locally available fuel. Like draining, logging stirred debate about environmental justice.

The Graham brothers' logging activities were part of a more widespread conversion of woodlands into arable, the extensive use of wood and timber for fuel, fences, and railway sleepers. The increasing pace of deforestation was also caused by a further liberalization of the economy, including important sections of the limestone industry. Not unlike the actions of the Mire Company, the extensive clearings projected by the foreign industrialists and their mobile steam powered sawmills, soon became subject to critical scrutiny. Claims about the illegality of their enterprise and a morale of discontentment were recurring themes in local discourse (Palmenfeldt 1976). As a mythopoetic gesture of sorts, the brothers Alexander and Patrick Graham were scornfully called the Grimm brothers: a direct reference to the illustrious German collectors of folk tales, Jacob and Wilhelm Grimm (Melin 1957). This allusion summoned a nightmarish world set in what Jack Zipes has called "enchanted forests", with infamous scenes of horror and violence that at the time shocked their bourgeois audience (Zipes 1988). In the Grimm-Graham conflation, geographical history and myth seemed to be perceived as equally valid modes of shared social consciousness on Gotland.

Despite the modernity of the logging enterprise, the Graham Brothers yearly shipped around 40 ships of lumber from Gotland to England; a massive number, including more than half of all export of staves from Sweden in the late 1860s (Sverne 1970, pp. 30-31). Meanwhile, the County Council worried that the Grahams were overexploiting the island's resources and expressed fears for a pending "ruinous forest destruction" due to the advance of modern sawmills (BiSOS H 1856-1860). From these discussions, the scale of exploitation and the foreign capitalist capture of Swedish resources appeared as two distinct distributional features of logging as a matter of environmental justice. According to various calculations, overexploitation of woodlands (for fuel, grazing, fencing, lumber, etc.) had been a longstanding problem, taken up by the Rural Economy and Agricultural Society of Gotland and the County Council already long before the 1860s and also after the 1870s, when the Grahams had left the island (Falkman 1851; Melin 1945, p. 339; Söderlund 1952; Sjöberg 1998). Not only did the policy makers express worries about dwindling access to resources by peasants, but also about long-term yield.

In the standard regional description on woodlands of 1877, Per Arvid Säve mentions the liberalization of lime-works in 1845 had an adverse impact on Gotland, causing these distributional issues. Liberalization of the industry was combined with the tendency against the customary use amongst peasants, i.e. to "trade, sell and chaffer with ancestral land," including a "dissolute bargaining for farms only to gain access to the woods". It would soon turn Gotland "into the ugliest landscape in the country" (Säve 1980, pp. 297-298). The steam powered sawmills ravaged the island: "The past few years, English capital using circular saws has been relentlessly cutting through major swats of whole parishes at a time, thereby demolishing the last solid estates with the island's best pine forests" (Säve 1980, p. 298). A plea to an environmental justice of sorts followed from these landscape changes. "The innocent," he pointed out, "were forced to suffer with the guilty, because once the latter have ravaged their forest, the neighbor has lost protection against storms" (Säve 1980, p. 300). For Säve, Gotland was "really threatened," "deforestation would turn into a future misery" and it was necessary for the Gotlanders to "think about their future generations" (Säve 1980, 299). The conservation debate entering public discourse on Gotland through the writings of Säve and others, parallels international developments concerning conservationism.

\section{From exploitation to conservation}

The third, and final development that I want to comment on, concerns forms of nature conservation and sustainable yield, appearing at a time when draining and logging continued, yet building on previous grievances about environmental justice in the form of resource loss. Aided by land redistribution, developments in agronomy, scientific experiment and detailed surveying of the geomorphology and hydrology of the island, technical difficulties encountering 
draining were largely overcome by the late nineteenth century. State-supported conversion of mires came in its wake and this arrangement reached its high point in the early twentieth century (Malmros 1889, 1890; von Feilitzen 1896, 1899). With the encroaching projects of draining mires and logging increasingly palpable in the landscape, concern with long-term effects and conservation appeared, which resulted from experiences with soil and woodland degradation, climatic and hydrological change, and a more overarching need to control nature in order to secure sustained harvests.

Deforestation featured prominently in the advocacy for the establishment of nature reserves and national parks in Sweden in early twentieth century (Mels 1999). Some decades before these policies gained force, Gotland was the first province in Sweden for which sustainable yield legislation was enacted in 1869. The peasantry's worries about the Graham Brothers' logging activities on the island were cited as important motifs behind the legislation, which mainly embodied regulations on replanting (Sverne 1970, p. 32). In the following decade, and troubled by the economic recession of the 1870s, the Graham Brothers company would abandon Gotland. However, largescale export of lumber from the island continued. Throughout the final decades of the nineteenth century, concern about increasing vulnerability to storm damage, draughts, soil degradation, and climatic changes on the island due to draining and deforestation were addressed in public discourse and policy making. Afforestation of drained mires was launched as one solution, while at the same time a continuing ditching of woodlands and underdraining of fields continued to increase productivity (GLH 1880-1899).

Around the turn of the century, the authorities organized a forest committee to improve management of the forests and in 1908, a more effective legislation was adopted to enforce sustainable yield principles on the island. By the 1920s, these provisions were incorporated in the national forestry law (GA 1902; Melin 1945, pp. 346-350). These historical shifts were already captured perfectly in a lengthy newspaper article from 1903: "In the past, protection against demolition of forests would be contrived by restrictions to individual use rights, mainly to secure certain businesses' and the state's need for lumber. Thereafter the inalienable property rights to the forest was thought to bring about the development of sound private forest management. While the consequences of these latter ideas became increasingly palpable, a new way of seeing appeared, aiming at the immediate promotion of proper management of the forest for its own sake" (GA 1903).

Interestingly, the new legislation initially roused a substantial degree of local disconcert because it was seen as an interference with the peasants' right to decide over their property. Over the course of a few decades, indignation about foreign capital and their unjust exploitation of the forests had thus turned into indignation about authorities and their enforcement of replanting, prohibitions, and sustainable yield policies. While these forms of contestation cannot be said to solely emanate from environmental concern, they did question the right to the landscape and its natural resources and were set against the future-oriented environmental concern of the policy makers.

Building on a powerful appraisal of mire nature as the socio-natural nexus of customary use and ecological value, and the forest as a resource under threat, it became increasingly clear that the nineteenth-century zeal for improvement had lost some of its former appeal. Institutions and individuals promoting a modern concern with nature conservation directed increasing attention to what was left of the original mires and woodlands. Scientists and local naturalists would express a sense of loss that prefigures the indispensability of species argument, notably concerning the loss of flora and birdlife (Sernander 1917; Romell 1947). The extensive struggles over Lina mire (draining), Gotska Sandön national park (logging) in the prewar-period, and, more recently, Ojnareskogen (logging and limestone quarrying), are striking cases in this respect (Engström 1926; Ohlsson 1961; SEPA 2018). Recently, such widely covered public struggles, with their combination of environmental, employment, and hydrological discourses aired in the diverse forums of legal deliberation and activism in the field, may perhaps go some way to a more general understanding of the contested, contradictory production of landscape on Gotland (The Guardian 2012; Anshelm et al. 2018). They clearly also extend the indispensability of species debate to the scale of landscape ecology. 


\section{Conclusion}

If there is one key insight that the environmental justice movement has consistently been voicing over the past four decades, it must be this: environmental concern and social justice do not exist in separate realities but need to be seen as coexisting and developing interdependently. As suggested in this paper, there is much to be gained for landscape ecology from an extended engagement with this field of social theory. Firstly, such an engagement can uncover capitalism's crisis-prone relation to its ecological conditions of possibility (its boundary struggles) and the particular landscapes this produces. The landscape ecologies of woodlands and wetlands discussed here thus bears testimony to capitalism's "deep-seated ecological contradiction, which inclines it non-accidentally to environmental crisis" (Fraser 2021, p. 97). Secondly, such an engagement provides insights into how the landscape, as "a place of human habitation and environmental interaction", conditions and is conditioned by environmental justice struggles along the axis of distribution, recognition, and participation (Olwig 2019, p. 22). Thirdly, such an engagement connects present landscapes to the past. Far from being self-explanatory, environmental justice is historically entangled with a contested material and discursive process of landscape production. By extension, therefore, this moves scholarly engagement with environmental justice to the deep historical geography and ecology of landscape change. The massive capitalist transformation of mires and woodlands on Gotland has illustrated such an engagement, including diverse forms of resource exploitation and conservation, and how they instantiated different modalities of environmental justice. Such analysis of the production of landscape in the past in terms of environmental justice, helps to discern important connections between the past and present politics of landscape, environment, and justice.

Acknowledgements This work was supported by the Swedish Research Council, Grant Number 201601934. Comments by two anonymous reviewers improved the argument of this paper. The usual disclaimers apply.

Funding Open access funding provided by Uppsala University.
Open Access This article is licensed under a Creative Commons Attribution 4.0 International License, which permits use, sharing, adaptation, distribution and reproduction in any medium or format, as long as you give appropriate credit to the original author(s) and the source, provide a link to the Creative Commons licence, and indicate if changes were made. The images or other third party material in this article are included in the article's Creative Commons licence, unless indicated otherwise in a credit line to the material. If material is not included in the article's Creative Commons licence and your intended use is not permitted by statutory regulation or exceeds the permitted use, you will need to obtain permission directly from the copyright holder. To view a copy of this licence, visit http://creativecommons.org/licenses/by/4.0/.

\section{References}

Agyeman J (2013) Introducing just sustainabilities: policy, planning, and practice. Zed Books, London

Agyeman J, Bullard RD, Evans B (2003) Just sustainabilities: development in an unequal world. Earthscan, London

Anshelm J, Haikola S, Wallsten B (2018) Ojnarekonflikten och miljöfrågans återpolitisering. In: Anshelm J, Haikola S, Wallsten B (eds) Svensk gruvpolitik i omvandling aktörer, kontroverser, möjliga världar. Gidlunds förlag, Möklinta, pp 75-99

Bellamy Foster J (2000) Marx's ecology: materialism and nature. Monthly Review Press, New York

BiSOS H (1856-1860) Bidrag till Sveriges officiella statistik, Serie H, Kongl. Maj:ts befallningshafvandes femårsberättelser, 1856-1860. Statistics Sweden, Stockholm

Bryant B (1995) Environmental justice: issues, policies, and solutions. Island, Washington, DC

Bryant B, Callewaert J (2008) Why is understanding urban ecosystems important to people concerned about environmental justice? In: Marzluff JM et al (eds) Urban ecology. Springer, Boston, pp 597-605

Buckingham S, Kulcur R (2010) Gendered geographies of environmental injustice. In Pain $\mathrm{R}$ et al Spaces of environmental justice. Wiley-Blackwell, Malden, MA, pp 70-94

Bullard RD (1990) Dumping in Dixie. Westview, Boulder

Chen S, Sleipness OR, Christensen KM, Feldon D, Xu Y (2019) Environmental justice and park quality in an intermountain west gateway community: Assessing the spatial autocorrelation. Landsc Ecol 34(10):2323-2335

Cosgrove DE, Daniels S (eds) (1988) The iconography of landscape: essays on the symbolic representation, design and use of past environments. Cambridge University Press, Cambridge

Egoz S, Jørgensen K, Ruggeri D (2018) Defining landscape democracy: a path to spatial justice. Edward Elgar, Northampton

Engström A (1926) Gotska Sandön. Bonnier, Stockholm

Falkman L (1851) Underdånig berättelse om en af öfver-direktören vid landtmäteriet genom rikets norra län och Gottland år 1850 verkstäld embetsresa. Stockholm 
Farina A (2006) Principles and methods in landscape ecology: toward a science of landscape. Springer, Dordrecht

Fegraeus L (1888) Om Gotlands Myrar Svenska Mosskulturföreningens Tidskrift 1:58-61

Fraser N (2003) Social justice in the age of identity politics: Redistribution, recognition and participation. Fraser N, Honneth A, Redistribution or recognition? A politicalphilosophical exchange. Verso, London, pp 7-109

Fraser N (2009) Scales of justice. Columbia University Press, New York

Fraser N (2014) Behind Marx's hidden abode: for an expanded conception of capitalism. New Left Rev 86(4):55-72

Fraser N (2021) Climates of capital. New Left Rev 127(1):94-127

GA (1902) I skogslagsfrågan: belysande inlägg. Gotlands Allehanda January 17

GA (1903) Den svenska skogslagstiftningens historia. Gotlands Allehanda May 8

GLaT (1859) Om Myr-odlingen (en kort historisk belysning) (insändt). Gottlands Läns nya Tidning 11 February

GLH (1880-1899) Gotlands läns hushållningssällskaps handlingar. Gotlands läns hushållningssällskap, Visby

GT (1859a) Angående myrodlingen på Gotland (forts.). Gotlands Tidning, 18 February

Harvey D (1996) Justice, nature and the geography of difference. Blackwell, Oxford

Holifield R, Porter M, Walker G (eds) (2010) Spaces of environmental justice. Wiley-Blackwell, Malden, MD

Honneth A (2008) Reification: a new look at an old idea. Oxford University Press, Oxford

Ihre MF (1841) Berättelse om Gottlands Läns nu femtioåriga Hushållnings-sällskap. A. Cedergren, Wisby

Jones M, Stenseke M (eds) (2011) The European landscape convention: challenges of participation. Springer, Dordrecht

GT (1859b) Tjuls - Gullauser. Gotlands Tidning, 5 August

Krueger R, Agyeman J (2005) Sustainability schizophrenia or "actually existing sustainabilities?" Toward a broader understanding of the politics and promise of local sustainability in the US. Geoforum 36(4):410-417

Lefebvre H (1968) The sociology of Marx. Allen Lane The Penguin Press, London

Lefebvre H (1991) The production of space. Basil Blackwell, Oxford

Lindström A (1879) Praktiskt geologiska iakttagelser under resor på Gotland 1876-1878. SGU Ser. C Avhandlingar och uppsatser 34

Lunddahl O (1852) Till Sweriges landtbrukare och allmoge om bildande af bolag till odling af mossar och kärr, samt om ängswattning, strömrensning och sjöars uttappning. Huldberg, Stockholm

Malmros DA (1889) Några erfarenhetsrön om myrodling på Gotland. Svenska Mosskulturföreningens Tidskrift 2:382-386

Malmros DA (1890) Gotland och dess myrodling. Svenska Mosskulturföreningens Tidskrift 3:22-31

Matless D (2012) In the nature of landscape: cultural geography on the Norfolk Broads. Wiley-Blackwell, Oxford

Melin R (1945) Den gotländska skogen. In Boken om Gotland 2. Stockholm, pp 333-362
Melin R (1957) "Bröderna Grimms" skogsrörelse på Gotland och dess förutsättningar. Gotländskt Arkiv 1957:69-81

Mels T (1999) Wild landscapes: the cultural nature of Swedish national parks. Lund University Press, Lund

Mels T (2014) Primitive accumulation and the production of abstract space: 19th-century mire reclamation on Gotland. Antipode 46(4):113-133

Mels T (2016) The trouble with representation: landscape and environmental justice. Landsc Res 41(4):417-424

Mels T (2020) The deep historical geography of environmental justice: accumulation, conservation and national park planning in Sweden. Annales De Géographie 736(3):31-54

Metzger JP (2008) Landscape ecology: perspectives based on the 2007 IALE world congress. Landsc Ecol 23:501-504

Mitchell D (2012) They saved the crops: labor, landscape, and the struggle over industrial farming in Bracero-era California. University of Georgia Press, Athens

Moberg I (1938) Gotland um das Jahr 1700. Stockholms Universitet, Stockholm

Musacchio LR (2013) Key concepts and research priorities for landscape sustainability. Landsc Ecol 28(6):995-998

Naveh Z (2007) Landscape ecology and sustainability. Landsc Ecol 22:1437-1440

O'Connor J (1998) Natural causes: essays in ecological Marxism. Guilford Press, New York

Ohlsson A (1961) Lina myr. LT, Stockholm

Olwig KR (2019) The meanings of landscape: essays on place, space, environment and justice. Routledge, Abingdon

Olwig K, Mitchell D (eds) (2008) Justice, power and the political landscape. Routledge, London

Palmenfelt U (1976) Bysen som traditionsdominant på Gotland. Gotländskt Arkiv 1976:23-40

Pellow DN (2016) Toward a critical environmental justice studies: black lives matter as an environmental justice challenge. Du Bois Review-Social Science Research on Race 13(2):425-425

Pellow DN (2018) What is critical environmental justice? Polity Press, Cambridge

Pellow DN, Brulle RJ (eds) (2005) Power, justice, and the environment. The MIT Press, Cambridge

Pettersson R (ed) (2015) Sågad skog för välstånd: den svenska sågverksindustrins historia 1850-2010. Kungl. Skogs- och Lantbruksakademien, Stockholm

Pulido L (1996) Environmentalism and economic justice. The University of Arizona Press, Tucson

Romell L-G (1947) Det gamla Gotland. Ymer 67(2):108-196

Runefelt L (ed) (2008) Svensk mosskultur: odling, torvanvändning och landskapets förändring 1750-2000. Kungl. skogs-och lantbruksakademien, Stockholm

Sandler R, Pezzullo PC (eds) (2007) Environmental justice and environmentalism: the social justice challenge to the environmental movement. The MIT Press, Cambridge

Säve PA (1980 [1876-1877]) Gotländska skrifter, vol. 3. Hanseproduction, Burgsvik

Schlosberg D (2007) Defining environmental justice. Oxford University Press, Oxford

Schlosberg D (2013) Theorising environmental justice: the expanding sphere of a discourse. Environ Polit 22(1):37-55

SEPA (2018) Fördjupad förstudie nationalpark Bästeträsk, Rapport 6843. Naturvårdsverket, Stockholm 
Sernander R (1917) Skogsvård och naturskydd: föredrag vid skogsdagarnas öppnande den 3 maj 1917. Stockholm

Sjöberg ÅG (1998) Den gotländska skogen under 1600-talet: exportnäring och hot om skogsbrist. Från Gutabygd 1998:48-62

Smith N (2010) Uneven development: nature, capital, and the production of space, 3rd edn. Verso, London

Söderlund E (ed) (1952) Swedish timber exports 1850-1950: a history of the Swedish timber trade. Almqvist \& Wiksell, Stockholm

Sverne B (1970) Graham Brothers På Gotland Gotländskt Arkiv 1970:21-42

Sylvan CA (1892) Gotlands naturbeskaffenhet, jordbruksförhållanden, dess myrars utsträckning och beskaffenhet samt äldre och nyare försök till deras odlande. Svenska Mosskulturföreningens Tidskrift 5:214-244

Sylvan CA (1899) Senare årens myrodling på Gotland. Svenska Mosskulturföreningens Tidskrift 12:186-194

Taylor C (1992) The politics of recognition. In: Gutmann A (ed) Multiculturalism: examining the politics of recognition. Princeton University Press, Princeton, pp 25-93

The Guardian (2012) Battle over mining in ancient forest goes to Sweden's highest court. The Guardian 17 September von Feilitzen C (1896) Några anteckningar från en resa på Gotland sommaren 1896. Svenska Mosskulturföreningens Tidskrift 9:240-244

von Feilitzen H (1899) Svenska Mosskulturföreningens sommarmöte på Gotland, den 12-14 juli 1899. Svenska Mosskulturföreningens Tidskrift 12:204-212

Walker G (2012) Environmental justice: concepts, evidence and politics. Routledge, Abingdon

Wu J, Hobbs R (2002) Key issues and research priorities in landscape ecology: an idiosyncratic synthesis. Landsc Ecol $7: 335-365$

WW (1847a) Om Martebo-myrs aftappning (insändt). Wisby Weckoblad, 22 January

WW (1847b) Till Redactionen för Wisby Weckoblad! Wisby Weckoblad, 15 January

Wylie J (2007) Landscape. Routledge, Oxdon

Young IM (1990) Justice and the politics of difference. Princeton University Press: Princeton

Zipes JD (1988) The brothers Grimm: from enchanted forests to the modern world. Routledge, New York

Publisher's Note Springer Nature remains neutral with regard to jurisdictional claims in published maps and institutional affiliations. 